\title{
HUBUNGAN PENYAKIT PENYERTA DENGAN TERJADINYA INFEKSI NOSOKOMIAL LUKA OPERASI PADA PASIEN
}

\author{
Nova Rita \\ AKPER 'AISYIYAH PADANG \\ Email :novaiit@gmail.com
}

\begin{abstract}
ABSTRAK
Infeksi nosokomial menyebabkan kesakitan dan kematian. Menurut WHO infeksi nosokomial menimbulkan kasus 9\% dari 1,4 juta di rumah sakit. Kejadian ILO di Indonesia 2$18 \%$, sedangkan di RSUP Dr. M. Djamil Padang infeksi nosokomial daerah luka operasi 16,52\%. Hasil observasi dari 10 orang pasien didapatkan $60 \%$ mengalami infeksi. Survei awal tindakan perawatan luka pada 5 dari 6 orang pasien belum sesuai dengan SPO. Penelitian bertujuan untuk mengetahui Hubungan Penyakit Penyerta Yang Mempengaruhi Terjadinya Infeksi Nosokomial Luka Operasi Pada Pasien. Jenis penelitian deskriptif analitik dengan pendekatan cross sectional. Penelitian dilakukan dari bulan November 2015-Agustus 2016 di Ruang Rawat Inap Bedah RSUP Dr. M. Djamil Padang tahun 2015. Sampel penelitian adalah 45 orang pasien yang telah dioperasi dan dirawat lebih dari 3 hari. Analisis data menggunakan analisis univariat dan bivariat. Hasil penelitian menunjukkan infeksi nosokomial 35,6\%, ada penyakit penyerta $62,2 \%$. Uji chi-square disimpulkan terdapat hubungan yang signifikan antara, penyakit penyerta $(\mathrm{p}=0,023)$, dengan terjadinya infeksi nosokomial luka operasi pada pasien di ruang rawat inap bedah RSUP Dr. M. Djamil Padang tahun 2016. Kepada pihak rumah sakit selalu memperhatikan peralatan yang akan digunakan, serta perawat melakukan tindakan sesuai prosedur, sehingga mengurangi angka infeksi.
\end{abstract}

\section{Kata kunci : Infeksi Nosokomial, Penyakit Penyerta}

\section{ABSTRACT}

infection of Nosocomial cause death and painfulness. According to WHO infection of nosokomial generate case 9\% from 1,4 million at home pain. Occurence of ILO in Indonesia 2-18\%, while in RSUP Dr M. Djamil Padang infection of nosocomial wound operate area for $16,52 \%$. Result of observation from 10 patient people got $60 \%$ experiencing of infection. Survey early action wound of treatment at 5 from 6 patient people not yet as according to SPO. Where it was analytical description with approaching sectional cross. Research conducted on November 2015- of Agustus 2016 at RSUP Dr M. Djamil Padangin 2015. The research sample are 45 patients was operated and taken care of day to 3. Data analysis used univariat and bivariate. The research result show that infection of nosocomial 35,6\%, comorbidities about $62,2 \%$. Chi-Square test concluded there are relation is significant between comorbidities ( $p=$ $0,023)$, operation type ( $p=$ with the happening of infection of nosokomial wound of operate at patient surgical inpatient unit at general hospital Dr M. Djamil Padang in 2016. To hospital always pay attention equipments to be used, and also nurse action according to procedure, so that lessen infection number.

Keyword : Infection of nosocomial, comordibities 


\section{PENDAHULUAN}

Infeksi nosokomial merupakan infeksi yang diperoleh atau terjadi di rumah sakit yang menyebabkan meningkatnya angka kesakitan dan kematian. Ada beberapa jenis infeksi nosokomial yang sering ditemukan di rumah sakit diantaranya : infeksi luka operasi, infeksi saluran kencing (ISK), hepatitis virus akut, infeksi aliran darah primer dan infeksi saluran nafas (Septiari, 2012). Menurut Depkes RI (2001) dalam Fatimah (2011), ada 4 macam infeksi nosokomial yang sering ditemukan di rumah rakit yaitu: Surgical Site Infection (Infeksi Luka Operasi), Ventilator Asosiated Pneumonia (Pneumonia Ventilator), Infeksi Saluran Kemih (ISK), dan Infeksi Aliran Darah Primer (IADP) atau Phlebiti. Dari jenis-jenis infeksi nosokomial diatas infeksi luka operasi menduduki urutan paling tinggi dipelayanan kesehatan terutama di Rumah Sakit.

Infeksi luka operasi (ILO) merupakan masalah yang sebenarnya bisa dihindari. Infeksi luka operasi dapat terjadi karena masuknya bakteri yang berasal dari rongga tubuh kedalam luka (infeksi endogen), dan dapat pula karena masuknya bakteri yang berasal dari luar atau dari permukaan tubuh kedalam luka (infeksi eksogen). Infeksi endogen umumnya berasal dari isi rongga / saluran sewaktu dinding rongga/ saluran tersebut dipotong/dirobek. Infeksi eksogen terjadi melalui udara dikamar operasi, dan dapat pula terjadi karena kontak lansung antara luka dengan bakteri yang ada pada permukaan tubuh atau bakteri yang berasal dari alat dan tangan operator. Faktor yang mempengaruhi terjadinya infeksi nosokomial luka daerah operasi yaitu terdiri dari faktor intrinsik dan ektrinsikPrawirohardjo (2004), dalam Fatimah (2011).

Faktor intrinsiknya dapat disebabkan oleh umur, jenisi kelamin, status gizi, penyakit penyerta, dan berat badan, sedangkan faktor ektrinsiknya dapat disebabkan karena persiapan pre operasi, kategori operasi, klasifikasi kondisi, jenis operasi, dan perawatan luka.Faktor intrinsik terdiri dari faktor umur dan penyakit penyerta. Menurut (Potter \& Parry, 2005) infeksi lebih rentan terjadi pada usia dewasa tengah dan lnjut usia dengan rentang umur 30-60 tahun, karena telah menyaring pertahanan terhadap infeksi. Flora normal, pertahanan system tubuh, inflamasi, dan respon imun memberikan perlindungan terhadap mikroorganisme yang menginvasi. Virus merupakan penyebab infeksi yang paling sering pada dewasa tengah dan lanjut usia.

Usia lanjut juga lebih rentan terjadi infeksi karena fungsi dan organ tubuh mengalami penurunan dan juga sistem imun juga mengalami perubahan dan berhubungan dengan penurunan resistensi tubuh terhadap infeksi. Kondisi ini lebih diperberat apabila penderita penyakit kronis seperti tumor, anemia, leukemia, diabetes melitus, gagal ginjal dan AIDS. Tidak semua penderita yang berada dalam satu ruangan perawatan akan tertular infeksi nosokomial, namun ada sejumlah penderita yang perlu diwaspadai karena adanya faktor predisposisi dan faktor resiko. Faktor predisposisi adalah faktor yang dimiliki oleh penderita yaitu adanya kerentanan pada tubuh penderita (Septiari, 2012).

Berdasarkan wawancara dan survey awal yang dilakukan pada tanggal 20 sampai 26 Januari tahun 2016 pada perawat ruangan bahwa pasien yang telah dioperasi pada umumnya dirawat di ruangan rawat inap bedah pria dan ruangan rawat inap bedah wanita. Hasil observasi dari 10 orang pasien yang telah dilakukan operasi yang dirawat di ruang rawat inap Bedah RSUP Dr. M. Djamil Padang didapatkan $60 \%$ mengalami infeksi yang ditandai dengan adanya pus pada daerah operasi. Pasien yang mengalami infeksi tersebut didapatkan, 4 orang pasien yang memiliki riwayat penyakit penyerta yaitu penyakit diabetes melitus 
Berdasarkan pemaparan dari latar belakang di atas maka peneliti telah melakukan penelitian tentang "Hubungan Penyakit Penyerta dengan Terjadinya Infeksi Nosokomial Luka Operasi pada Pasien di Ruang Rawat Inap Bedah RSUP Dr. M. Djamil Padang Tahun 2016”.

\section{METODE PENELITIAN}

Pada penelitian ini mengunakan desain penelitian deskriptif analitik, kemudian datanya dianalisis hubungan antar variabel. Lokasi penelitian dii di Ruang Rawat Inap Bedah RSUP. Dr.M. Djamil Padang. Waktu Pelaksanaan penelitian ini dilaksanakan mulai November 2015 - Agustus 2016 orang pasienyang telahdioperasi dan dirawat lebih dari 3 hari di Ruang Rawat Inap Bedah.

\section{HASIL PENELITIAN}

Hasil penelitian ini menjelaskan tentang analisa univariat dan bivariat pada variabel dependen Infeksi Nosokomial dan variabel independen; penyakit penyerta sebagai berikut :

Tabel 1.1

Hubungan Penyakit Penyerta Terjadinya Infeksi Nosokomial Luka Operasi Pada Pasien dibandingkan dengan pasien yang tidak ada memiliki penyakit penyerta $(11,8 \%)$.Hasil uji statistikchi-squaredidapatkan $\mathrm{p}$ value $=$ $0,023$ ( $p \leq 0,05)$, sehingga Ho ditolak berarti dapat disimpulkan bahwa ada hubungan yang bermakna antara penyakit penyerta responden dengan terjadinya infeksi pada luka operasi yang pasien di ruang rawat inap bedah RSUP Dr. M. Djamil Padang tahun 2015. Nilai OR (Odd Ratio) didapatkan 7,500, yang artinya pasien yang memiliki penyakit penyerta mempunyai peluang 7 kali untuk terjadinya infeksi nosokomial luka post operasi pada pasien.

\section{PEMBAHASAN}

\section{Infeksi nosokomial pada luka operasi pada pasien post operasi}

Hasil penelitian yang dilakukan peneliti dengan observasi menggunakan lembaran check list kepada 45 pasienpost operasi yang dirawat di Ruang Rawat Inap Bedah RSUP Dr. M. Djamil Padang, terdapat kurang dari separuhyaitu 16 orang pasien $(35,6 \%)$ mengalami infeksi nosokomial pada daerah luka operasi, sedangkan 29 pasien $(64,4 \%)$ yang tidak mengalami infeksi nosokomial daerah luka operasi.

Penelitian yang sama dilakukan olehFatimah (2011), tentang Faktor- faktor yang berhubungan dengan terjadinya infeksi nosokomial luka operasi di ruang rawat bedah RSUP Fatmawati Tahun 2011. Hasil penelitian menunjukkan bahwa 6 orang pasien $(8,8 \%)$ yang mengalami infeksi nosokomial pada daerah luka operasi. Hasil penelitian ini berbanding terbalik dengan penelitian yang didapatkan Asyifa, dkk (2012), tentang Faktor- faktor yang berhubungan dengan infeksi nosokomial luka operasi yang mana hasil penelitian didapatkan 35 orang pasien $(64,8 \%)$ yang mengalami infeksi pada daerah luka operasi.

Menurut WHO (2005) dalam Asyifa, dkk (2012), infeksi luka operasi
Berdasarkan tabel 1.1 menunjukan hasil bahwa proporsi kejadian infeksi nosokomial lebih tinggi terjadi pada pasien yang memiliki penyakit penyerta $(50,0 \%)$ 
(ILO) merupakan salah satu komplikasi pasca bedah dan merupakan masalah yang serius, karena dapat meningkatkan morbiditas, dapat menyebabkan kecacatan dan bahkan kematian. Menurut Septriari (2012), infeksi nosokomial merupakan salah satu penyebab utama dan meningkatnya angka morbilitas dan mortalitas yang dapat menghambat proses penyembuhan, sehingga mengakibatkan masalah baru dalam bidang kesehatan, antara lain meningkatnya hari rawat dan biaya perawatan serta pengobatan pasien di rumah sakit.

Infeksi nosokomial dapat memberikan dampak yaitu menyebabkan cacat fungsional, serta stress emosional dan dampak menyebabkan cacat permanen dan kematian, dampak tertinggi pada negara berkembang dengan prevelensi HIV/AIDS yang tingi, meningkatkan biaya kesehatan diberbagai negara yang tidak mampu dengan meningkatkan lama perawatan di Rumah Sakit, pengobatan dengan obatobatan mahal dan penggunaan pelayanan lainnya, morbilitas dan mortalitas semakin tinggi, ada tuntutan secara hukum, penurunan citra Rumah Sakit.

Menurut Septriari

(2012), pencegahan terjadinya Infeksi nosokomial yaitu membatasi tranmisi organisme dari atau antar pasien dengan cara mencuci tangan, dan menggunakan sarung tangan, tindakan dan aseptik, sterilisasi dan disinfeksi, mengontrol resiko penularan dari lingkungan, melindungi pasien dengan penggunaan antibiotika yang adekuat, nutrsis yang cukup, dan vaksinasi, membatasi resiko endogen dengan meminimalkan proses invasif, pengawasan infeksi, identifikasi, dan mengontrol penyebarannya.

Menurut analisa peneliti infeksi nosokomial luka operasi terjadi dapat dilihat lebih dari 3 hari setelah pasien di operasi, karena dimulai dari hari ke 3 perban pada luka operasi pertama kali dibuka. Saat itu luka sudah mulai terlihat infeksi atau tidak infeksinya pada luka post operasi pada luka operasi pasien tersebut. Dimana tanda- tanda dari infeksi tersebut yaitu ada pus yang keluar dari luka/drain, tepi kulit terlihat mengalami inflamasi/ kemerahan, nyeri pada jaringan yang mengalami infeksi, rasa panas pada darah yang mengalami infeksi, pembengkakan pada daerah operasi, dan perubahan fungsi dari jaringan yang mengalami infeksi. Luka operasi dapat dikatakan infeksi apabila terdapat minimal 3 dari tanda- tanda infeksi tersebut.

Berdasarkan hasil dari observasi dan lembaran check list oleh peneliti, diantara 6 dari tanda- tanda tersebut tandatanda yang sering terlihat yaitu pembengkakan pada luka operasi $35(78 \%)$ dari 45 orang pasien, rasa panas pada daerah yang mengalami infeksi 31 (69\%), rasa panas ini dapat nilai ketika peneliti melakukan wawancara dengan pasien ketika sudah dilakukan perawatan luka post operasinya. Nyeri pada jaringan yang mengalami infeksi 23 (51\%), rasa nyeri yang dirasakan pasien dapat dilihat ketika perawat melakukan tindakan perawatan pada luka post operasi pasien, saat perawatan luka dilakukan pasien terlihat meringis dengan skala nyeri (skala 4).

Kemerahan pada tepi kulit luka operasi 21 (47\%), kemerahan ini dapat dilihat langsung ketika perban pada luka post operasi pasien dibuka saat perawat melakukan perawatan luka pada luka post operasi pasien. Pus yang keluar dari luka operasi $16(35,5 \%)$ dari 45 pasien post operasi, pus/ drain ini dapat dilihat ketika perawat melakukan perawatan luka pada luka post operasi pasien, dimana pada saat perawat melakukan perawatan luka perawat sedikit menekan luka yang mengalami infeksi dan kemudian dari luka tersebut keluar pus/ drain.

\section{Penyakit Penyerta pasien Post Operasi yang dirawat di Ruang Rawat Inap Bedah}

Hasil penelitian yang dilakukan peneliti dengan observasi menggunakan 
lembaran check list kepada 45 pasienpost operasi yang dirawat di Ruang Rawat Inap Bedah RSUP Dr. M. Djamil Padang, didapatkan lebih dari separuh 28 orang pasien $(62,2 \%)$ memilki penyakit penyerta yang beresiko terjadinya infeksi nosokomial daerah luka operasi, sedangkan 17 orang pasien $(37,8 \%)$ tidak memilki penyakit penyerta.

Penelitian yang sama dilakukan Kurniasari Septi \& Fajar Yudha (2011), tentang faktor- faktor yang mempengaruhi kejadian infeksi nosokomial luka operasi di ruang bedah RS Imanuel Bandar Lampung, hasil penelitian menunjukan 48 orang pasien $(60,8 \%)$ yang menderita diabetes melitus yang beresiko terjadinya infeksi nosokomial daerah luka operasi, dimana penyakit yang menyertai ini akan berpengaruh terhadap proses penyumbuhan luka post operasi.

Menurut Potter \& Parry (2005), penyakit yang menyertai yang diderita pasien seperti diabetes melitus, leukemia dan HIV merupakan salah satu faktor yang mengambat untuk proses kesembuhan luka. diantaranya penyakit kronik seperti diabetes melitus menyebabkan timbulnya penyakit pembuluh darah kecil yang dapat mengganggu perfusi jaringan. Diabetes juga menyebabkan hemoglobin memiliki afinitas yang lebih besar untuk oksigen, sehingga hemoglobin gagal melepaskan oksigen kejaringan. Hiperglikemia mengganggu kemampuan leukosit untuk melakukan fagositosi dan juga mendorong pertumbuhan infeksi. Sklerosis multipel juga rentan terhadap infeksi karena kelemahan umum dan gangguan nutrisi.

Menurut Potter \& Parry (2005) kelemahan umum dan gangguan nutrisi beresiko terhadap infeksi. Leukemia, AIDS, limfoma, dan anemia aplastik merupakan kondisi yang membahayakan hospes dengan melemahkan pertahanan melawan organisme infeksius. Klien leukemia tidak mampu memproduksi sel darah putih dalam jumlah yang cukup untuk mencegah infeksi. Klien penyakit kronik seperti diabetes melitus dan sklerosis multipel juga rentan terhadap infeksi karena kelemahan umum dan gangguan nutrisi.

Hasil analisa peneliti dimana pasien yang memiliki penyakit penyerta sangat berpengaruh terhadap proses penyembuhan luka post operasi. Sehingga dengan luka yang lama sembuh dan terkontaminasi oleh mikroorganisme sangat beresiko terhadap infeksi luka operasi pada pasien. Penyakit penyerta yang sangat berpengaruh terhadap terjadinya infeksi seperti diabetes melitus, leukemia dan HIV.

Diabetes melitus merupakan salah satu penyakit penyerta yang berkaitan dengan memperlabat proses kesembuhan pada luka operasi pasien, yang mana pasien yang memilki penyakit penyerta diabetes melitus ini mengalami peningkatan pada kadar gula dalam darahnya sehingga proses kesembuhan pada luka post operasi menjadi lambat. Lambat atau lamanya luka pada post operasi pasien sembuh dan ditambah dengan luka terpapar dengan patogen yang berbahaya terhadap luka, maka dari situlah luka post operasi pada pasien post operasi menjadi infeksi.

Infeksi nosokomial pada luka post operasi pasien juga dapat dipengaruhi oleh penyakit leukemia yang diderita pasien, dimana leukemia ini berkaitan dengan produksi sel darah putih dalam jumlah yang cukup sehingga menghambat dalam proses kesembuhan pada luka post operasi pada pasien. Luka post operasi juga dapat dipengaruhi oleh penyakit HIV yang diderita pasien, dimana HIV ini berkaitan juga dengan melemahnya sistem imun tubuh untuk melawan patogen yang berbahaya bagi tubuh terutama pada luka post operasi.

\section{Hubungan penyakit penyerta dengan Terjadinya Infeksi Nosokkomial Pada Daerah Luka Operasi Di Ruang Rawat Inap Bedah}

Berdasarkan hasil penelitian
menunjukan hasil bahwa infeksi
nosokomial daerah luka operasi terjadi pada 
pasien yang memiliki penyakit penyerta yaitu $(50,0 \%)$ dan hanya sebagian pasien tidak terjadi infeksi nosokomial $(11,8 \%)$. Pada uji Chi-Square didapatkan $\mathrm{p}$ value $=$ $0,02(\mathrm{p} \leq 0.05)$, artinya ada hubungan yang bermakna antara penyakit penyerta dengan terjadinya infeksi nosokkomial pada daerah luka operasidi Ruang rawat Inap Bedah RSUP Dr. M. Djamil Padang Tahun 2015. Nilai OR (Odd Ratio) didapatkan 7,500, yang artinya pasien yang memiliki penyakit penyerta mempunyai peluang 7 kali untuk terjadinya infeksi nosokomial luka post operasi pada pasien.

Penelitian yang sama dilakukan Kurniasari Septi \& Fajar Yudha (2011), tentang Faktor- faktor yang mempengaruhi kejadian infeksi nosokomial luka operasi di ruang bedah RS Imanuel Bandar Lampung. Menunjukan hasilbahwa $81,3 \%$ infeksi nosokomial terjadi pada responden yang memiliki penyakit penyerta dengan nilai $\mathrm{p}$ value $=0,043(\mathrm{p} \leq 0.05)$. Hasil penelitian yang sama juga didapatkan dari penelitian deni riskiawa, dkk (2011), tentang hubungan lama hari rawat dan penyakit yang menyertai dengan terjadinya infeksi nosokomial pada luka operasi di RSI Sultan Hadlirin Jepara. Menunjukan hasil yaitu $55,6 \%$ infeksi nosokomial terjadi pada pasien yang memiliki penyakit penyerta dengan nilai $p$ value $0,003(p \leq 0.05)$.

Prawirohardjo (dalam Fatimah, 2011) menjelaskan bahwa pasien dengan penyakit kronis seperti Diabetes, kanker/keganasan. Gangguan faal hati, gangguan faal ginjal, pasien immunocompromised misalnya pasien dengan penyakit yang disebabkan oleh Human Immunodefisiency Virus (HIV) atau Acquired Immune Deficiency Syndrome (AIDS), pasien dengan penggunaan kortikosteroid kronis seperti yang terjadi pada penderita asma atau perokok berat atau pengguna tembakau lainnya secara signifikan mempunyai resiko terjadi infeksi yang lebih besar.

Menurut analisa peneliti penyakit penyerta merupakan penyakit yang diderita pasien post operasi sebelum masuk rumah sakit. Sehingga dengan penyakit yang diderita pasien nantinya sangat berpengaruh terhadap kondisi luka pada daerah operasi pada pasien. Pasien yang memiliki penyakit penyerta seperti diabetes melitus, dimana pasien yang memiliki penyakit penyerta diabetes melitus yaitu 7 $(15 \%)$ orang pasien dari 45 orang pasien.

Pada pasien diabetes melitus sebelum dilakukan tindakkan pembedahan, terlebih dahulu harus menstabilkan kondisi atau menstabilkan kadar gula darah untuk menghindari adanya bahaya yang mengancam hidup pasien pada saat dilakukan tindakan pembedahan ataupun setelah dilakukan tindakan pembedahan dan kemudian dirawat di ruang rawat inap bedah. Ketika pasien post operasi telah dirawat di ruang rawat inap bedah juga perlu menjaga kestabilan kadar gula darahnya, sehingga nantinya tidak berpengaruh atau jadi salah satu faktor penghambat terhadap proses penyembuhan pada luka post operasi pada pasien tersebut. Sehingga disitulah luka terkontaminasi oleh patogen- patogen yang berbahaya bagi luka tersebut dan kemudian barulah luka mengalami infeksi.

Disamping penyakit penyerta diabetes melitus yang diderita pasien juga ada pasien pasien menderita leukemia yaitu $21(46,6 \%)$ orang pasien dari 45 orang pasien. Leukemia ini sangat berpengaruh juga dalam proses kesembuhan luka, dimana pada pasien yang menderita leukemia ini harus dilakukan transfusi darah sehingga sel darh putih tersebut cukup untuk membantu dari proses kesembuhan luka. Sehingga luka post operasi pada pasien post operasi tidak mengalami infeksi nosokomial pada luka post operasi. 


\section{KESIMPULAN}

Hasil penelitian menunjukkan bahwa Kurang dari separuh pasien post operasi $(35,6 \%)$ yang terjadi infeksi nosokomial pada daerah luka operasi. Ada hubungan bermakna antara penyakit penyerta pasien post operasi dengan terjadinya infeksi nosokomial pada daerah luka operasi di Ruang Rawat Inap Bedah RSUP Dr. M. Djamil Padang Tahun 2016. Kepada pihak rumah sakit selalu memperhatikan peralatan yang akan digunakan, serta perawat melakukan tindakan sesuai prosedur, sehingga mengurangi angka infeksi.

\section{DAFTAR PUSTAKA}

Arikunto, Suhasimi. 2010. Prosedur Penelitian Suatu Pendekatan Praktik. Jakarta: Salemba.

Arias Katheleen Mechan, 2009. Investigasi Dan Pengendalian Wabah Di Fasilitas Pelayanan Kesehatan. Jakarta: EGC

Asyifa Ainus, dkk, 2012. Faktor- Faktor Yang Berhungan Dengan Infeksi Nosokomial Luka Operasi. www.jurnal.stikes-nanihasanudin.ac.id. Diakses pada tanggal 20 April 2015.

A Potter, Anne Griffin Perry, 2005. Buku Ajar Fundamental Keperawatan: Konsep, Proses dan Praktik. Ed 4. Jakarta: EGC.

Baradero, 2008. Keperawatan Perioperatif: prinsip dan praktik. Jakarta: EGC

Darmadi, 2008. Infeksi Nosokomial: Problematika dan pengendalian. Jakarta: Salemba Medika.
Dharma, 2011. Metodologi Penelitian Kesehatan. Jakarta: EGC

Fatimah Siti, 2011. Faktor- Faktor yang Berhubungan Dengan terjadinya Infeksi Nosokomial Luka Operasi Di Ruang Bedah RSUP Fatmawati. http://skripsi.Universitaspembangun an"Veteran".ac.id. Diakses pada tanggal 20 Maret 2015.

Hidayat, 2009. Metode Penelitian Keperawatan dan Teknik Analisis Data. Jakarta: Salemba Medika.

Himatusujanah \& Faizah Betty Rahayuningsih. Hubungan Tingkat Kepatuhan Pelaksanaan Protap Perawatan Luka Dengan Kejadian Infeksi Luka Post Operasi Sectio Caesarea (SC) Di Ruang Mawar RSUD DR. Moewardi Surakarta. www.jurnal-ilmu-

keperawatan.ac.id. Diakses pada tanggal 23 juli 2015.

James Joyce, Colin Baker \& Helen Swain, 2006. Prinsip- Prinsip Sains Untuk Keperawatan. Jakarta. Erlangga.

KEPMENKES, RI. 2008. Standar Pelayanan Minimal Rumah Sakit. http://www.kepmenkes.go.id.

Diakses pada tanggal 15 Maret 2015.

Haryanti Lina, dkk, 2013. Prevelens Dan Faktor Resiko Infeksi Luka Operasi Pasca Bedah.www.jurnal-ilmukeperawatan.ac.id. Diakses pada tanggal 10 juni 2015.

Notoatmodjo, Seokidjo. 2007. Kesehatan Masyarakat Ilmu dan Seni. Jakarta: Rineka Cipta.

Notoatmodjo, Seokidjo 2010. Promosi Kesehatan Teori dan Aplikasi. Jakarta: Rineka Cipta. 
Notoatmodjo, Seokidjo 2012. Metodologi Penelitian Kesehatan. Jakarta: Rineka Cipta.

Nugraheni, 2012. Infeksi Nosokomial. ww w.jurnal.universitas-

diponegoro.ac.id. Diakses pada tanggal 05 Januari 2015.

Nursalam, 2011. Konsep Dan Penerapan Metodologi Penelitian Ilmu Keperawatan. Ed 2. Jakarta: Salemba Medika.

Nurulhuda Uun, dkk, 2013. Analisis Hubungan Kepatuhan Perawat Terhadap Penerapan Metode Universal Precaution Dengan Penyembuhan Luka Operasi. www.jurnal-keperawatanpoltekes-kemenkes-jakarta-I.ac.id. Diakses pada tanggal 25 juli 2015.

Mariana Dina \& Baharuddin, 2014. Gambaran Tekhnik Perawatan Luka Pasien Post Operasi Sectio Caesarea (SC) Pada Proses Penyembuhan Luka Fase Inflamasi. www.journal-of-medical-surgicalnursing.ac.id. Diakses pada tanggal 27 juli 2015.

Nwankwo Eo, dkk, 2012. Incidence And Rist Factors of Surgical Site Infection In a Tertiary Helth Institution In Kano. International Journal of InfectionControl. Diakses pada tanggal 20 juli 2015.

Ristiawan Deni, dkk, 2013. Hubungan Antara Lama Perawatan Dan Penyakit Yang Penyertai Dengan Terjadinya Infeksi Nosokomial Pada Luka Operasi. www.Jurnal-Ilmukeperawatan.ac.id. Diakses pada tanggal 09 Juni 2015.

Septiari, 2012. Infeksi Nosokomial. Yogyakarta: Nusa Medika.
Setiadi, 2007. Konsep dan Penulisan Riset Keperawatan. Ed I. Yogyakarta. Graha Ilmu.

Kurniasari Septi \& Fajar Yudha, 2011. Faktor-Faktor Yang Mempengaruhi Kejadian Infeksi Nosokomial Luka Post Operasi Di Ruang Bedah Rumah

Sakit Imanuel Bandar Lampung. $\underline{\mathrm{w}}$ ww.jurnal-kesehatan-mitralampung.ac.id. Diakses pada tanggal 27 juni 2015.

Sari , 2013. Faktor-Faktor yaNg Mempengaruhi Infeksi Nosokomial Pada Luka Operasi Di Ruang Bedah RSUP RSUP Fatmawati. http://skripsi.Universitaspembangun an"Veteran".ac.id. Diakses pada tanggal 20 Maret 2015.

Sjamsu hidayat dkk, 2004. Buku Ajar Ilmu Bedah. Edisi 2. Jakarta: EGC.

STIKes Dharma Landbouw Padang, 2015. Pedoman Penulisan Karya Tulis Ilmiah/Skripsi. Pedoman Tidak Diterbitkan. Padang : PSIK/STIKes Dharma Landbouw.

Sugiyono, 2013. Metode Penelitian Kuantitatif Kualitatif Dan R\&DAdministrasi. $\quad$ Bandung: Alfabeta.

Puspitasari Herlina Abriani, dkk, 2011. Faktor-Faktor Yang Mempengaruhi Penyembuhan Luka Post Operasi Sectio Caesarea (SC) Di PKU Muhammadiayah Gombong tahun 2011.www.jurnal-ilmiah-kesehatankeperawatan.ac.id. Diakses pada tanggal 15 juli 2015. 
Tim PPIRS, 2014. Laporan Kinerja Mutu Dan Mamfaat Bagi Masyarakat Komite Pencegahan Dan Pengendalian Infeksi Rumah Sakit. Padang.

Rosaliya Yosi, dkk, 2011. Faktor- Faktor Yang Mempengaruhi Kejadian Infeksi Nosokomial Pada Pasien Luka Post Operasi Di RSUD Tugurejo Semarang Tahun 2011.www.jurnal.stikes-telogorejosemarang.ac.id. Diakses pada tanggal 25 Juni 2015. 